\title{
A Review of Public Housing Delivery System in Ogun State, Nigeria
}

\author{
Orekan, Atinuke Adebimpe \\ ${ }^{1}$ Department of Estate Management, College of Environmental Sciences, Bells, University of Technology, Ota, \\ Ogun State, Nigeria \\ *Corresponding author: tinuorekan33@gmail.com
}

\begin{abstract}
The importance of housing in Nigeria and the various housing strategies formulated by the Ogun state government in solving housing problems and efforts that have been made to-date has been acknowledged. Despite those efforts, it seems that much has not been achieved in terms of the availability of affordable housing. This paper provides a review of the housing programmes as well as public housing delivery in Nigeria with a further examination of the public housing delivery in Ogun State. In order to achieve this aim, a review of the relevant literature pertaining to public housing is made. A primary data gathering exercise is made with the senior officials at the Ogun State Housing Corporation (OSHC) to uncover the challenges as well as the strategies in place for the provision of affordable housing in Ogun State. The data was then supported with data from housing files obtained at the agency. It was revealed that OSHC has four (4) basic public estates in which allocation is made to the public. It was also noted in this study that (OSHC) is tilted to profit-making instead of social welfarism. This has made housing less affordable to the low and medium income earners.
\end{abstract}

Keywords: Housing; Housing Affordability, Housing Delivery, Ogun State Housing Corporation

\subsection{INTRODUCTION}

Shelter, one of the basic necessities to human existence cannot be undermined. Provision of affordable houses has been a major task facing Nigeria government despite the fact that it is part of their agenda at the beginning of their tenure. The availability of housing stock could determine the wealth base of any nation. Nubi (2010) discussed that the housing market has contributed to a significant proportion of the GDP. He further showed that residential mortgages alone contribute over $87 \%$ of the GDP in Denmark and $71 \%$ in the USA. In the UK it is slightly lower at $70 \%$ while in Germany residential mortgages contribute 54\% of its GDP, Hong Kong stands at 31\% and Nigeria comparatively lower at $0.8 \%$. This implies that the effort of Nigerian government in improving housing stock has not gone far as regards the provision of affordable houses.

The population in Nigeria as at the last count of the population census in 2006 is that the nation is over 140 million and 35\% live in the cities. Nubi (2015) opined that Nigeria is facing the problems of overcrowding, homelessness and squatting in the major cities and this is prominent in cities like Enugu, Kano, Lagos and Ibadan. He also expressed that Sub-Saharan Africa has the highest population of slum dwellers with a figure of $71.8 \%$, Nigeria inclusive. Falade (2007) found that more than $62 \%$ of the population will be living in urban centres in Nigeria by the year 2020, which implies an annual population increment of $2.8 \%$, all other factors being equal. As such, the housing preparedness of the Nigerian government has received attention.

Most policies of the past and present government in Nigeria have only been concentrating on the urban cities while rural areas have been neglected and the housing problem is expected to be tackled at the urban and rural areas. The availability of decent houses with basic amenities at the rural areas will deter rural-urban migration and the effort of government in resolving housing problems will 
be felt. As it is now in Nigeria, it looks as if housing problems cannot be easily solved. This could be because of failure of past policies with regards to housing. Some of the noticeable problems associated with housing policies in Nigeria are lack of proper implementation, inadequate funding, lack of credit facility and low incentive to investors.

The nature of the housing deficit in Ogun state most especially in the urban areas is not different from other parts of the country. In view of this, the study aims to identify public housing delivery system in Ogun State with a view to examining the various housing strategies in place for low and medium income earners and recommend improvements as necessary.

\subsection{LITERATURE REVIEW}

\subsection{An Evolution of Housing Programmes in Nigeria}

The history of housing policy in Nigeria dated back in 1928 in Lagos. The policies are modest with the ultimate aim of addressing the housing problems at a national scale (Omange and Udegbe, 2000). As the population increases, the existing system is no longer adequate to handle current housing issues due to its outdatedness. Aribigbola (2008) confirmed that construction of senior civil servant quarters in the capital city of Lagos and regional headquarters like Kaduna, Ibadan and Enugu are some of the practical efforts made by the government in the earlier years. This is to say that during this era, their focus was to cater for their staff members.

During this era, the policy objectives include;

1.) Promulgation of legislations to maintain construction standards, planning of housing areas and sanitation;

2.) Provision of housing subsidy and rent control;

3.) Land reform through the promulgation of land use decree of 1978.

In order to achieve these objectives, several institutions were established by the colonial administration including the Urban Councils in 1946, the Lagos Executive Board (LEBD) in 1954, the Nigeria Building Society (NBS) and the Regional Housing Corporation Act in 1959. Waziri and Rookie (2013) explained that the Nigerian Building Society was a replica of the post-second world war British system where mortgage bank known as building societies were established to allow for housing opportunities within both public and private sectors. However, NBS depended only on the government to finance it. This was another stumbling block for NBS to perform effectively. Between 1975 and 1980, 202,000 houses were planned to be provided to the public but only 28,500 units were realised.

For further improvement, the federal government established the Federal Housing Authority through the promulgation of Decree No.40 of 1973. The Federal Housing Authority started its operation formally in 1976. FHA took up its main responsibility in providing houses for people between the years 1975 and 1980. This led to the creation and development of Ipaja Town, Amuwo Odofin Phase 1 Estate and FESTAC Town, which is the first of all-African Festivals of Arts and Culture (FESTAC). This was the first low- cost housing scheme that was created by the federal government. After this, the federal government attempted to solve medium and high income through the development of 350 housing units by FHA (Federal Housing Authority) in all of the 19 states then in the federation. This is in addition to the 1975/80 housing programme. The federal government also embarked on another low-income housing scheme, popularly referred to as Shagari Quarters throughout the federation under the supervision of the Federal Ministry of Housing and Enlistment (NHP, 2006).

Table 1 below shows the numbers of housing units delivered in the states of the federation of Nigeria between the periods 1980-1983 ranging from 1 bedroom to 3bedroom flats. 
Table 1: No. of delivered housing according to State in Nigeria.

\begin{tabular}{|l|l|l|}
\hline S/NO & \multicolumn{1}{|c|}{ STATE } & \multicolumn{1}{|c|}{$\begin{array}{c}\text { HOUSING } \\
\text { UNITS }\end{array}$} \\
\hline 1. & FCTA & 1,908 \\
\hline 2. & Anambra & 2,400 \\
\hline 3. & Bauchi & 2,816 \\
\hline 4. & Bendel & 1,422 \\
\hline 5. & Benue & 1,980 \\
\hline 6. & Borno & 2,807 \\
\hline 7. & Cross River & 2,258 \\
\hline 8. & Gongola & 3,038 \\
\hline 9. & Imo & 2,758 \\
\hline 10. & Kaduna & 2,7716 \\
\hline 11. & Kano & 1,590 \\
\hline 12 & Kwara & 2,462 \\
\hline 13. & Lagos & 2,634 \\
\hline 14. & Niger & 2,692 \\
\hline 15. & Ogun & 2,160 \\
\hline 16 & Ondo & 2,930 \\
\hline 17. & Oyo & 2,128 \\
\hline 18. & Plateau & 2,546 \\
\hline 19. & Rivers & 1,580 \\
\hline 20 & Sokoto & 2,314 \\
\hline & TOTAL & $\mathbf{4 7 , 5 0 0}$ \\
\hline & & \\
\hline
\end{tabular}

Source: Nubi, (2010)

In the year 2000, the government viewed housing problems from another perceptive. Due to the concern of housing affordability, the government establishes the Federal Ministry of Housing and Urban Development with a view of reforming the housing policy. As part of the housing reform that took place from 2000-2004, the policy focused on the private sector for a faster means of delivering housing while the public sector concentrated on infrastructure for new housing development. In addition, issues related to the Land Use Act were also examined (Bustani and Kabir, 2010). Reviews were also made to the financial structure such as the FMBN (Federal Mortgage Bank of Nigeria) and provision of incentives to developers, such as informing them of the tax break. Abdullahi (2010) observed that the present policy recognises the private sector as the main solution to the housing deficit in the country while the government opts to function as an enabler and facilitator in housing delivery.

The main objective of the Nigerian Housing Policy 2006 is to ensure that Nigerians own or have access to decent, safe and healthy housing at an affordable price. Unfortunately, the policy has not been able to meet its objectives. Aribigbola, (2008) reveals in his study that the policy was supposed to cater for low-income earners who are the majority of city residents, yet failed to deliver housing unit under the programme. He argued that the policy has not made a sufficient contribution to housing provision. Bustani and Kabir (2010) and Daramola (2006) had highlighted on the issue of land use regulation to be reviewed for easy accessibility of land while Oduwaye (1998) suggested a simple land allocation model.

\subsection{Concept of Good Public Housing Delivery System}

There are government Ministries and Parastatals involved in housing delivery in Nigeria. The Federal Ministry of Housing is the regulatory body in housing policy and delivery, while at the state level, there is the Ministry of Housing across the nation. In the housing industry, private sectors 
participate in housing provision and sometimes collaborate with the public sector to facilitate housing delivery. Daramola (2006), has made it known that despite the fact that the role of ministry and government parastatals is necessary for housing provision, the bureaucracy and lengthy regulatory approval process limit the efficient participation of private sectors in housing delivery. Since 2006, government participation in housing delivery has been through public-private partnership programme (PPP).

Despite these facts, the government should pursue policies that can yield improvement to the housing stock, especially for the low-income earners. In Australia, the government promoted schemes that increased housing stock for the people. Eslake (2013) observed that from 1947 to 1961, housing stock increased by $50 \%$ with $41 \%$ increase in the Australian population. He further stated that between 1961 and 1976, housing stock increased by 46\% over stripping the 33\% increase in Australia's population and from 1976 to 1991, housing stock increased at a faster rate. All these improvements on housing stock were as the result of the formulation of policies and programmes to address affordable housing. Some of these policies include Housing Agreement, Common-Wealth State, National Housing Supply Council, State and Local Government Planning schemes and policies for the provision of urban infrastructure. Although it is worthy to note that there was a slight fall in housing stock in 2006-2011 for the first 100 years.

With government intervention and laudable policies like the development of import substitution industries, low-taxation on large scale industries and subsidising the cost of land title documents, the government can meet the objective of providing housing for all.

Several studies have shown different strategies offered in improving housing supply in Nigeria. Omole (2001) suggested an affordable financing model for housing, Oduwaye (1998) also advocated for a simple land allocation model and Fasakin (1998) opined that housing cooperative is a means of augmenting housing supply in the country.

In addition, Housing Corporation operates as property developers to the government. The funding comes from government budget allocations, these developers construct the units and sell them off to individuals who either pay in cash or make instalment payments during the period of construction. Although, most of the times, it is the medium-income earners that benefit from this policy. Lagos state has practised and implemented this scheme to some extent and it has worked for the state. Lagos State Development and Property Corporation seem to be the most active housing corporation in Nigeria. It was able to produce about 25,000 units since its inception about 35 years ago (Pison Company 2010).

\subsection{Housing Policy in Ogun State and Challenges}

Ibimilua and Ibitoye (2015) refer to the policy as a statement on paper by government or an establishment as regards the way and manner in which identified problems are to be solved. The provision of affordable housing has been one of the challenges faced in Nigeria. As a result, several policy papers were put forward to the Nigerian government regarding affordable housing in most cities in Nigeria.

In 2003 during the regime of the former governor, a housing policy in Ogun state known as the OGD Housing programme was formulated. This programme was initiated to achieve some benefits for the people of Ogun state. Among others, these benefits include; i) adequate housing for all people in the state, ii) a peaceful co-existence and social coherence amongst all social-economic group in the society, iii) security of land tenure and home ownership amongst all socio-economic group (Ogun State, Ministry of Housing, 2005). This policy will enable people in the state to own or have access to decent, safe and healthy housing accommodation. 


\subsection{Housing Delivery Strategies in Ogun State}

The challenges of housing delivery system are not only peculiar to Ogun State alone but also afflict other parts of Nigeria and even in other developing countries of the world. Adedipe and Lasisi (2006) opined that the magnitude of housing challenges in Ogun state relates to both the quality and quantity of housing, especially for low-income earners. This fact was further supported by the Ogun state Regional Plan (2005-2025) which noted that the quality of housing in Ogun state reflects underdevelopment of the housing sector in the state.

In Ogun State, the former governor initiated housing delivery strategies that will be beneficial to both the low and medium civil servants. These are the Core-Housing, Turnkey Housing, PublicPrivate Partnership Housing and Shell Stage Housing.

\section{Core - Housing Delivery Strategy:}

According to Greene and Rojas (2008), core-housing delivery became popular in the 1960s and early 1970s, when the government of developing countries embarked on large scale public housing schemes. The Swedish International Development Cooperation Agency in 1992 noted that this scheme was supported by aid from international aid agencies such as World Bank and United States Agency for International Aid (USAID). In the mid '70s, the Nigerian government had an arrangement with the World Bank in the provision of Core Housing delivery.

\section{Turnkey Housing Delivery Strategy}

This is diversification of housing markets through the sale of a completed housing unit to the public at an affordable price (Sengupta and Ganesan, 2004). This strategy involves various stages beginning from the acquisition of land to the stage of marketing the houses. In Ogun state, the turnkey housing scheme entails land acquisition and project design. This scheme is majorly funded through internal generated revenue and external loans. Under this scheme, there is "Aboismi" housing scheme where the government collects money from the Nigerian diaspora who are willing to have a property in Ogun state. This scheme is seen to address the issue of "Omo onile" (land grabbers) where owners are subjected to multiple payments for land documents.

\section{Public-Private Partnership (PPP) Housing Delivery Strategy}

It is a collaboration between the government and the private sector in housing delivery. Ong and Lenard (2002) and Ikekpeazuc (2004) opined that Public-Private Partnership (PPP) has the potential to address housing and service delivery challenges in many countries which will relief government and its agencies from financial and bureaucratic burdens. Gateway City Development Company Limited (GCDCL) had successfully participated in PPP housing scheme in Ogun state with private developers such as Grant Properties Limited and Spark Light Development Company Limited in the development of Havilah Villas Estate in Isheri and OGD-spark light Estate in Ibafo.

\section{Shell Stage Housing Delivery Strategy}

This strategy is different from the Core and Turnkey strategies. From the preliminary survey done with the Ogun State Housing Corporation, it was revealed that the strategy involves the acquisition of land and the construction of a so-called "Skeletal Structure". The finishing and supporting services would be left for the intending users to put in place. This is so because of the various complaints from buyers on the poor quality of finishing and structures in other public housing schemes. The house buyers will install windows, doors, sanitary wares and any other forms of finishing that suit their choices. The housing providers will provide the block walls, the roof, electricity and the laying out of the environment. Enquires that were made from OSHC further revealed that shell stage housing strategy brought about different development of housing within the estate. 
Figure 1: Framework of the Assessment of Public Housing Delivery system in Ogun State.

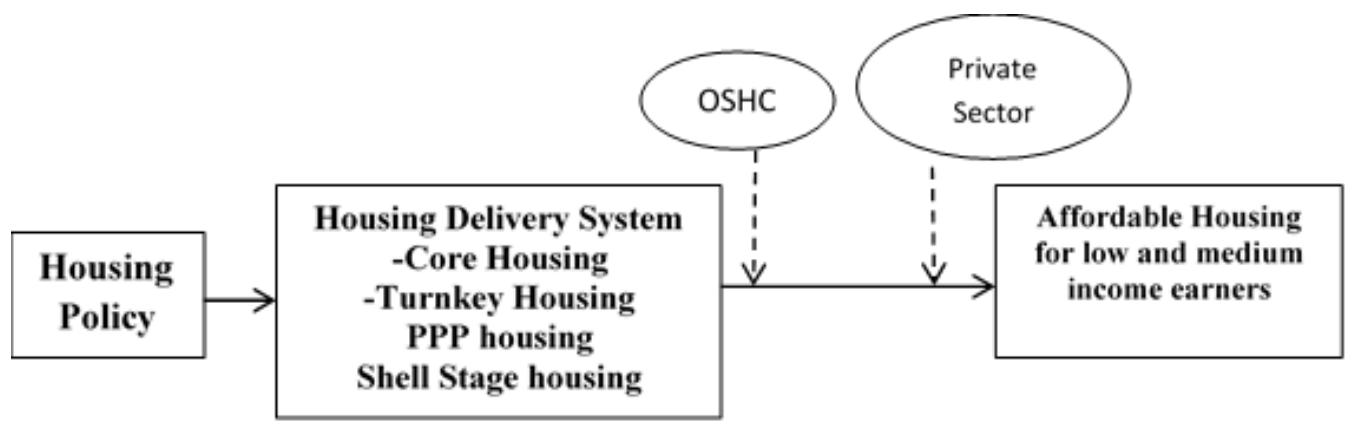

The framework as shown in Figure 1 indicates that housing policy entails National Housing Supply Council and good government planning schemes policy. Pursuing all of these will resort to a smooth housing delivery system in Nigeria. Housing delivery system is done through parastatals or ministry for ease of the delivery system. With the intervention of private developers, the government could regulate policies which in turn could influence the price of properties for people and for affordability. There could also be the adoption of joint venture in which there is the participation of government and private developers for the provision of housing. This will increase the housing stock and address housing accessibility challenge. With the sole participation of government in housing delivery, the government could provide housing loan to individuals to reduce the issues surrounding housing affordability.

\subsection{STUDY AREA: OGUN STATE}

Established in 1976, Ogun state is located in the South-western zone of Nigeria. It borders Lagos State in the South, Oyo and Osun States to the North, Ondo to the East and Republic of Benin to the West as shown in figure 2. Due to its strategic location as an entry point to the country from West Africa, Ogun state is referred to as the "Gateway State". It covers a total land area of $16,980.55 \mathrm{~km}^{2}(6,556.238 \mathrm{sqm})$. Abeokuta is the capital and the largest city of the State. It is noted for its concentration of industrial estates and a major manufacturing hub in Nigeria. The major factories located in Ogun state include Dangote Cement factory, Nestle and Lafarge Cement factory. Other urban infrastructural services such as road facilities, parks and public utilities are also provided in the state.

The 2006 census recorded a total population of 3,751,140 residents in Ogun state ranked $16^{\text {th }}$ of 36 states in the country. The state has twenty local government areas. The primary occupation of the people is agriculture and $80 \%$ of the total land area is arable. About $20 \%$ of its total area is constituted of forest reserve suitable for livestock. Mineral resources available include chalk, phosphate, high quality stones and gravels for construction works.

Figure 2: Map of Ogun State.

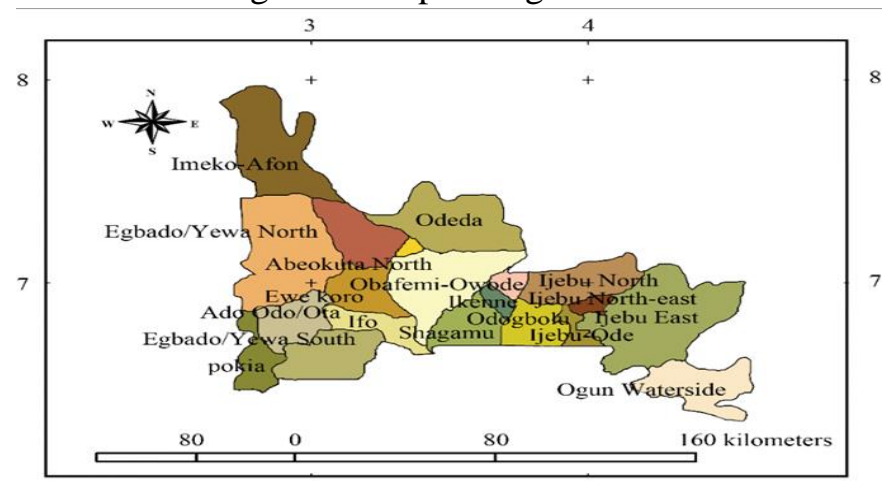

Sourcê: Biopublisher.ca,'2013. 


\subsection{PUBLIC HOUSING DELIVERY IN OGUN STATE}

In order to identify the public housing delivery in Ogun State, the examination of the strategies in place for the provision of affordable housing in the state were uncovered through primary data gathering. The government officials at the Ogun State Housing Corporation (OSHC) were contacted to give their feedback on several queries pertaining to the achievement of the aim of the study. Preliminary interviews were conducted amongst seven (7) senior officers at OSHC's Estate and Planning Unit (see Table 1). All interviewees possessed over 10 years' experience and have in-depth knowledge on the public housing provision in Ogun state. The purpose of the data gathering from these officers was to identify and examine the housing delivery system available to the government of Ogun state, to assess the capacity of housing agencies and parastatals in the delivery of housing estates and how affordable are these estates to the low and medium income earners. Document of the state Housing Corporation was also given for further extraction of information.

Table 2: Respondents (Staff in Estate and Planning Division, OSHC)

\begin{tabular}{|l|l|}
\hline RESPONDENTS & NO OF RESPONDENTS \\
\hline Estate Surveyors & 5 \\
\hline Town Planners & 1 \\
\hline Architect & 1 \\
\hline Total & $\mathbf{7}$ \\
\hline
\end{tabular}

Source: Field survey, 2019.

Table 2 revealed that most of the respondents at the Estate Unit of OSHC are Estate Surveyors and Valuers while two (2) of the other staff are from the allied profession.

From the information gathering exercise that was gathered from the officers and the documents that were accessible, it was found that the bulk of the data used was derived from the Estate unit of Ogun State Housing Corporation.

Table 3: Estates with their categories

\begin{tabular}{|l|l|l|}
\hline S/N & Estates & Housing categories \\
\hline 1. & Ibara Mews & Public-private partnership \\
\hline 2. & $\begin{array}{l}\text { Value-ville and AAK Degun workers } \\
\text { Estate }\end{array}$ & Core-Housing Estate \\
\hline 3. & HID Awolowo/Obsanjo Hilltop Estate & Turnkey Housing Estate. \\
\hline 4. & Ajebo Road Estate & Shell Stage Housing Estate. \\
\hline
\end{tabular}

Source: Author field survey,2019.

It was revealed that the categories the existing estate falls under the Housing Delivery Scheme established by the corporation and information given were that Ibara Mews, Ibara Abeokuta, falls under the PPP Housing Delivery scheme, HID Awolowo and Obsanjo HillTop falls under Turnkey Housing Estate, Ajebo Road Estate falls under Shell Stage Housing Delivery and Value-Ville and AAK Degun Workers Estate fall under Core-Housing Estate. The categories are indicated as in Table 3. 
Table 4: Housing Estates within OSHC

\begin{tabular}{|l|l|l|l|}
\hline S/No & Names Of Estate & Units & Accommodation \\
\hline 1. & Ibara Mews, Ibara, Abeokuta & 12 & 4 B/R duplex, Terrace House \\
\hline 2. & $\begin{array}{l}\text { HID, Awolowo, } \\
\text { Obsanjo Hilltop }\end{array}$ & 76 & $\begin{array}{l}\text { 4B/R duplex semi-detached, 3B/R } \\
\text { semi-detached. }\end{array}$ \\
\hline 3. & Ajebo Rd. Estate, Idi-Aba & 26 & $\begin{array}{l}\text { 4BR detached, 3BR detached shell } \\
\text { stage }\end{array}$ \\
\hline 4. & Value-Ville Estate, Oke-Ata & 112 & 1 BR semi-detached core houses \\
\hline 5. & $\begin{array}{l}\text { AAK Degun Workers Estate, } \\
\text { Laderin }\end{array}$ & 150 & $\begin{array}{l}\text { 2BR and 3BRsemi-detached block } \\
\text { of flats }\end{array}$ \\
\hline
\end{tabular}

Source: Field Survey,2019

Table 5: No. of Applicants of Estates and the Allocation by OSHC

\begin{tabular}{|c|c|c|c|}
\hline Name of Estates & $\begin{array}{c}\text { No. of applicants in } \\
(\mathbf{2 0 1 8})\end{array}$ & No. of Allotees & Amount (=N=) \\
\hline Ibara Mews & 12 & 6 & $45 \mathrm{M} /$ unit/Duplex \\
\hline $\begin{array}{c}\text { HID Awolowo, } \\
\text { Obasanjo HillTop }\end{array}$ & 10 & 3 & $25 \mathrm{M} /$ unit-3BRS \\
\hline Ajebo Road Estate Idi & 5 & 3 & $\begin{array}{c}3 \mathrm{BD}-7.5 \mathrm{M} \\
\text { 2BD- 7.0M }\end{array}$ \\
\hline $\begin{array}{c}\text { Value Ville Estate, } \\
\text { Oke-Ata }\end{array}$ & 105 & 48 & $3.5 \mathrm{M} / \mathrm{Unit}$ \\
\hline $\begin{array}{c}\text { AAR Degun workers } \\
\text { Estate }\end{array}$ & $\begin{array}{c}\text { Fully occupied except } \\
\text { for the back flats }\end{array}$ & - & $\begin{array}{c}\text { Mortgage for Civil } \\
\text { Servants }\end{array}$ \\
\hline
\end{tabular}

Source: Ogun State Housing Corporation, 2019

Table 4 and 5 show the housing estate within OSHC as well as the number of applicants and the allocation by OSHC respectively. It was revealed that in Ibara Mews, out of twelve (12) applicants, only six (6) of the applicants were given allocation and this represents only $50 \%$. Invariably, 50\% were not granted because they could not meet up with the requirements expected of them. Each applicant is expected to pay for the application processing fees, submit their tax clearance certificate, a guarantor's letter and statement of the bank account. All of these would be scrutinised by the board constituted by OSHC and recommendations sent to the Commissioner for Works and Housing before approval is granted and payment made to the government account. This process is applicable to all the government estates in the state. In HID Awolowo Obsanjo Hilltop, out of the ten (10) people that applied for the houses, only three (3) applicants got the request. This represents $30 \%$ of the total applicants. Ajebo Road Estate appears different in the sense that out of the five (5) applicants, the allocation was made to three (3), which represents $60 \%$. One hundred and five (105) applicants applied in Value-Ville Estate, only forty eight (48) of the applicants were given allocation, this represents $45.7 \%$ and in AAK Degun workers Estate all the houses have been fully occupied. 
Table 6: Payment Methods of Allottees of Properties at OSHC

\begin{tabular}{|l|l|l|ll|}
\hline S/N & Options & Names of Estate & Payment Structure \\
\hline 1. & Public Servant & $\begin{array}{l}\text { AAR Degun } \\
\text { workers Estate and } \\
\text { Ibara Mews }\end{array}$ & Monthly deduction \\
\hline 2. & Traders & $\begin{array}{l}\text { Value Ville Estate, } \\
\text { Oke-Ata }\end{array}$ & $\begin{array}{l}\text { Through PMI and Ogun state } \\
\text { Savings and Loan }\end{array}$ \\
\hline 3. & Farmers & - & \multicolumn{1}{|c|}{} \\
\hline 4. & Retirees & $\begin{array}{l}\text { AAR Degun } \\
\text { workers Estate and } \\
\text { Value Ville Estate, } \\
\text { Oke-Ata }\end{array}$ & $\begin{array}{l}\text { Through Ogun state Savings and } \\
\text { loans (Community Bank) }\end{array}$ \\
\hline 5. & Private Employees & $\begin{array}{l}\text { Ibara Mews and } \\
\text { HID Awolowo, } \\
\text { Obasanjo HillTop }\end{array}$ & $\begin{array}{l}\text { Through Ogun state Savings and } \\
\text { loans (Community Bank) }\end{array}$ \\
\hline
\end{tabular}

Table 6 shows the sets of applicant patronising Ogun State Housing Corporation (OSHC) to acquire properties. Public servants are the major occupant for AAR Degun and Ibara Housing Mews. This is as a result of the low price of properties and the convenient payment structure, while the private business owners and employees patronise the Ibara Mews, HID Awolowo and Obasanjo Hilltop Estates.

\subsection{DISCUSSION ON THE PUBLIC HOUSING DELIVERY IN OGUN STATE}

From the data gathering from the primary and secondary sources, it was revealed that ValueVille Estate and AAK Degun workers Estate are the core-housing estates which the state government embarked on for low-income and medium income earners. They are one-room semi-detached and 2/3 bedroom bungalows and block of flats as shown in Table 4. From Table 5, it is obvious that it has the largest allocation of estates compared to other estates. It is obvious from the same table that the price unit is more affordable than others. AAK Degun workers' estate is an estate with a mortgage plan for civil servants and this must have contributed to its $100 \%$ occupation by allottees.

From Tables 4 and 5, the cost per unit of 3 and 4 bedrooms semi-detached duplex and flats in HID Awolowo/ Obsanjo Hilltop estates is N25M. Table 5 further shows the proportion of assignee of that estate, about $30 \%$ of the applicants were allocated to this estate. Obviously, the price is not affordable to the low and medium income earners and this shows that the estate is for the high class. As at last survey carried out in Nigeria, an average monthly income for medium income earners is between N75,000 and N100,000 (US\$480 and \$645) (www.quora.com).

Ibara Mews is a high class housing delivery, fenced round and enclosed. It is a Joint-Venture programme i.e. with the participation of private developers and government in the provision of the housing scheme. The price of houses in the estate is N45M per unit and the allocation rate is $50 \%$ of the total applicants. It is an estate that has a good layout and provided with basic amenities.

From the various literature reviewed so far, it can be deduced that housing development is essentially tied to affordability and availability of land. The demand for housing in the inner part of cities is expensive; in which the access to sites in these areas is not affordable for the low-income earners. This is one of the reasons why the so-called not-for-profit housing developers cannot compete with the private sector. Housing delivery has been part of government policy, but it has not met up with the need of people in the country. The government are the owners of land in Nigeria, one would expect that with this huge resource (land), housing availability should be made a lot easier. The cost of titling and perfecting land document is a major setback to lots of people (middle and low- 
income earners). The time spent and the bureaucracy involved in the completion of land papers is another issue.

Direct participation of government in housing delivery has slowed down the affordability and availability of housing. The government have pushed it to private investors. Private investor's participation has not made houses affordable to the masses. Non-involvement of government and shifting the responsibility of housing delivery to a private sector that is at its infancy with neither financial nor technical capacity to delivery has grossly increased the housing deficit in developing countries.

It is well known that building construction is capital intensive. Finance is a major pillar in housing construction. The Federal Mortgage Bank of Nigeria (FMB), Primary Mortgage Institution's (PMI) impact in financing property construction cannot be felt, not much can be obtained from them. Nubi (2001) states that the poor performance of FMBN which gave loan to 874 out of 10,000 applicants between 1977 and 1990 was very worrisome. It is obvious that FMBN should undergo serious reengineering to be able to cope with the enormous task of housing finance. Continuity and implementation of government policies that have been tested and is beneficial to all should be allowed to continue even if government changes.

\subsection{CONCLUSION}

Government involvement in housing delivery should be a priority. It should be seen that providing a roof over people is one of their main responsibility. From the data that has been gathered from the primary and secondary sources within the Ogun State Housing Corporation, it is revealed that with government participation in housing delivery, affordability and desirability of housing by the masses can be arranged. AAK Degun estate in Ogun state is an indication of this. The availability of flexible and workable mortgage plan, the housing predicament for the people can be reduced. It is not something that should be totally shifted to the private developer, but a partnership between the government and the private sectors can be created. Though the private investor's aim is to make profit through the reflection on the price of the houses, the government's involvement could mitigate the issue through a form of subsidy.

\subsection{REFERENCE}

1. Adedipe B.O and Lasisi A.L (2006). "Government Policy as a Disincentive to Housing Innovation in Ogun State, Nigeria". The Built Environment: Innovation Policy and Sustainable Development. Ota-Nigeria. Department of Architecture, Covenant University, PP: 392-396.

2. Abdullahi, B (2010). “ Nigeria's Housing Policy and Public-Private Partnership (PPP) Strategy": Reflection in achieving home ownership for low-income group in Abuja- Nigeria. Urban Dynamics and Housing change, $22^{\text {nd }}$ International Housing Research Conference- $4^{\text {th }}$ $7^{\text {th }}$ July, 2012, Istanbul.

3. Aribigbola (2008)." Housing policy Formulation in Developing Countries": Evidence of programme implementation from Akure, Ondo State Nigeria. Journal of Human Ecology 23(2): 125-134, 2008.

4. Daramola, S.A (2006). Affordable and Functional Housing in a developing Economy. A case study of Nigeria. Journal of Land Use and Development Studies 2(1).

5. Eslake, S (2013): Australian housing Policy: 50 years of failure. A submission to the Senate Economics Reference Committee, $21^{\text {st }}$ December, 2013. 
6. Falade, F.O (2007). "Planned City as Foundation for Sustainable City". Being the text of a paper presented at the conference on sustainable cities, organised by the New Economic Partnership on African Development (NEDAD), held at Transcop Hilton Hotel, Abuja, May 27-30, 2007.

7. Fasakin, J.O (1998). Cooperative Housing; "The Concept, Experience and Applicability to Nigeria's Socio-Economic Millieu". Seminar Paper presented at the Department of Urban and Regional Planning, Federal University of Technology, Akure.

8. Federal Government of Nigeria; National Housing Policy Draft (2006).

9. Greene.M and Rojas.E (2008). Incremental Construction: A strategy to Facilitate Access to Housing. Environment and Urbanisation 20(1) 89-108.

10. Ibimilua and Ibitoye (2015). "Housing Policy in Nigeria": An overview. American International Journal of Contemporary Research, Vol. 5, No.2, April, 2015.

11. Ikekpeazue .C (2004). Government Housing Project and Assessment- The case of government Estate at oregbami Ikpoba Hill and Ogbowo. Dissertation for the award of Bachelor of Science degree in the Department of Geography and Regional Planning, University of Benin.

12. Nubi T.G (2001). "Housing Finance in Nigeria: Needed for Re-engineering". Housing Finance International Special Edition Services, June 2001.

13. Nubi T.G (2010). "Towards a Sustainable Housing Finance in Nigeria: The Challenges of developing adequate housing stock and road maps" Housing Finance International Summer, 2010.

14. Nubi T.G (2015). Beyond Bricks and Mortar, Inaugural lecture of Professor T.G Nubi, at the University of Lagos, Akoka, 2012.

15. Oduwaye, A.O (1998). "Urban Landscape Planning Experience in Nigeria". Landscape and Urban Planning 43(1-3); pp133-142, 1998.

16. Omange, O. and Udegbe, A. (2000). Way forward for Housing Supply in developing countries. An oblique view in Okewole et al (eds). Innovation, Policy and sustainable development in Ota, Nigeria, Department of Architecture, Covenant University, Ota, Ogun State. pp 348-354.

17. Omole, F.K (2001). Basic Issues in Housing Development, Ondo: Femo Bless Publishers.

18. Ong, H.C and Lenard. D (2002). Partnership between stakeholders in the provision of and access to affordable 5housing in Malaysia. Paper presented at FIG XII, International Congress held at Washington D.C, USA, April 19-22, 2002.

19. Sengupta, U and Ganesan, S (2004): The state role in popular Housing programmes in Shanghai: from provider to enabler to facilitator forum. 6(1) 52-57.

20. Waziri A and Rookie O (2013). Housing Finance in Nigeria: Need for Re-Engineering. Housing Finance International, Special Edition Series, June, 2013. 